-

\title{
VÝZNAM SEGMENTÁCIE PRI HODNOTENÍ KVALITY SLUŽBY Z POHLADU ZÁKAZNÍKOV SPOLOČNOSTI SLOVAK TELECOM
}

\author{
Stanislava Valovičová ${ }^{1}$, Lucia Vrábelová ${ }^{2}$
}

\section{Úvod}

Vzhl'adom k rastúcej konkurencii, vel'kému množstvu reklamných médií a distribučných ciest je $v$ dnešnej dobe obtiažne používat' hromadný marketing. Firmy sa preto častejšie vydávajú na cestu mikromarketingu zameraného na segmenty (identifikovatel'né skupiny zákazníkov na trhu), výklenky (úzke skupiny, ktoré možno určit' rozdelením trhového segmentu na subgegmenty alebo definovaním skupín zákazníkov s odlišnými špecifickými potrebami), lokálne oblasti alebo jednotlivcov.

\section{Segmentový marketing}

Za účelom vol'by trhu a pre úspešné pôsobenie na trhu mnoho firiem využíva cielený marketing, ktorý spočíva v troch základných krokoch. Sú to segmentácia trhu, definovanie ciel'ového trhu a trhové umiestňovanie, t.j. výber trhovej pozície na ciel'ovom trhu.

Uvedené kroky zahŕňajú identifikáciu hlavných trhových segmentov, špecifikáciu charakteristických čŕt trhových segmentov, vol'bu jedného alebo niekol'kých prít’ažlivých ciel'ových segmentov vhodných pre vstup, vývoj vhodnej marketingovej stratégie odpovedajúcej špecifickým zákazníckym potrebám a prianiam v danom trhovom segmente. Pri cielenom marketingu namiesto širokého výrobného a marketingového programu firmy sa kladie dôraz na prispôsobenie marketingového mixu požiadavkám ciel’ových zákazníkov.

\section{Etapy segmentácie trhu}

Existuje šest' etáp, ktoré sú nevyhnutné na definovanie stratégie segmentácie :

- definovat' celkový trh, na ktorom chce firma pôsobit' (z hl'adiska potrieb spotrebitel'ov),

- identifikovat' dostatočne vel'ké homogénne skupiny spotrebitel'ov,

- určit' profil segmentov v zmysle jeho odlišných postojov v správaní, v demografických a psychografických charakteristík,

- vykonat' analýzu vel'kosti segmentov trhu - ak sú segmenty identifikované, je potrebné ohodnotit' ziskový potenciál, ktorý predstavuje každý z nich pre firmu. Každý firmou obsluhovaný segment by mal byt' významný pre tvorbu dostatočných príjmov.

- vypracovat' marketingový mix, ktorý bude schopný reagovat' na špecifické potreby cielených segmentov,

- spájat' ciel'ové trhové segmenty na základe marketingu firmy, za predpokladu, že je akceptovatel'ný a že firma sa rozhodla aplikovat' ho.

\footnotetext{
${ }^{1}$ Ing. Stanislava Valovičová, PhD., Katedra spojov, Fakulta prevádzky a ekonomiky dopravy a spojov, Žilinská univerzita, Univerzitná 1, 01026 Žilina, tel.: 513 3133, e-mail: Stanislava.Valovicova@fpedas.utc.sk

${ }^{2}$ Mgr. Lucia Vrábelová, Katedra spojov, Fakulta prevádzky a ekonomiky dopravy a spojov, Žilinská univerzita, Univerzitná 1, 01026 Žilina, tel.: 513 3140, e-mail: Lucia.Vrabelova@fpedas.utc.sk
} 


\section{Typy segmentácie}

Segmentácia trhu spočíva vo vhodnom rozdelení trhu na homogénne časti, trhové segmenty, ktoré sa stanú pre firmu ciel'ovým trhom so špecifickým marketingovým mixom. Segment možno definovat' ako čast' trhu, ktorú tvoria spotrebitelia s podobnými vlastnost’ami, spotrebitel'ským správaním a nákupných rozhodovaním na danom trhu.

Namiesto vyhl'adávania trhových segmentov podl'a demografických charakteristík alebo životných štýlov môžeme rozlišovat' preferenčné segmenty. Môžu sa objavit' tri vzory:

- Homogénne preferencie - všetci zákazníci majú takmer rovnaké preferencie, takýto trh neobsahuje žiadne prirodzené segmenty.

- Difúzne preferencie - preferencie môžu byt' rozptýlené po celom priestore. Znamená to, že spotrebitelia sa vo svojich preferenciách podstatne odlišujú. Značka umiestnená do stredu osloví najviac potenciálnych zákazníkov a minimalizuje mieru neuspokojenia.

- Zhlukové preferencie - na trhu môže existovat' niekol'ko preferenčných zhlukov, ktoré nazývame prirodzené trhové segmenty. Prvá firma na trhu má tri možnosti. Môže umiestnit' výrobok do stredu, aby oslovil všetky skupiny zákazníkov, snažit' sa získat' pre seba najväčší segment (sústredený marketing). Môže vyvinút' niekol'ko výrobných značiek, každú pre odlišný segment.

\section{Postup segmentácie trhu}

Postup, ako možno rozpoznat' významnejšie segmenty na trhu sa skladá z troch fáz:

1. Prieskumná fáza - výskumník prevádza neformálny prieskum a zameriava sa na skupiny zákazníkov tak, aby porozumel ich motivácii, postoju a správaniu sa. Na základe výsledku pripraví formalizovaný dotazník, ktorý sa predloží vybranému súboru respondentov. Ciel’om dotazníka je zhromaždit' informácie:

- požadované vlastnosti produktu a ich významnost',

- vedomie o značke a hodnotenie značiek,

- spôsob používania produktu,

- postoj k danej kategórii výrobkov,

- demografické, psychografické a mediagrafické údaje o respondentoch.

2. Analytická fáza - výskumník použije faktorovú analýzu pre odstránenie vysoko korelovaných premenných. Potom použije zhlukovú analýzu pre vytvorenie určitého počtu maximálne odlišných segmentov.

3. Fáza profilovania - v tejto fáze sa vymedzí profil každého zhluku v zmysle odlišných postojov, správania sa, demografických, psychografických zvykov. Každý segment je možné nazvat' podl'a dominujúcej charakteristiky.

Jedným zo spôsobov ako nájst' nové segmenty je pátrat' po hierarchii vlastností, podl'a ktorých si zákazníci vyberajú tovary a služby. Tento proces sa nazýva štiepenie trhu. Proces segmentácie trhu sa však musí periodicky opakovat', lebo trhové segmenty sa časom menia.

\section{Metodika skúmania závislosti medzi vybraným trhovým segmentom a hodnotením kvality služieb}

Pri segmentácii trhu možno využit’ široké spektrum premenných. Obvykle sa v praxi najčastejšie používajú geografické, demografické a psychografické segmentačné charakteristiky. V rámci tohto príspevku je pozornost' venovaná štyrom demografickým premenným, a to konkrétne pohlaviu, veku, dosiahnutému vzdelaniu a povolaniu zákazníkov.

Demografické kritériá patria k oblúbeným základom pre rozlišovanie skupín zákazníkov. Dôvodom je skutočnost', že potreby, priania a preferencie zákazníkov sú často silne spojené s demografickými premennými a demografické premenné sú l'ahšie meratel'né ako väčšina iných typov premenných. Dokonca i v prípade, že ciel'ový trh je popísaný inak 
ako podl'a demografických charakteristík, pre zistenie vel'kosti ciel'ového trhu a určenie médií pre efektívnu komunikáciu je nutné opätovné prepojenie k demografickým charakteristikám.

Úlohou je skúmat', či vybrané segmenty zákazníkov vykazujú navzájom odlišné potreby, priania a priority. Ciel'om tohto príspevku je prostredníctvom testu nezávislosti v kontingenčných tabul'kách hl'adat' odpoved' na otázku, či existujú určité špecifické postoje vybraných segmentov vzhl'adom kjednotlivým dimenziám kvality služby poskytovanej zákazníkom spoločnosti Slovak Telecom, a.s.

Zdrojom sekundárnych dát pre riešenie uvedenej úlohy boli výsledky prieskumu uskutočneného $v$ rámci diplomovej práce č. 28/2005 Mariany Klučárovej s názvom „Hodnotenie úrovne predajných procesov v sieti telekomunikačných operátorov“. Ako vstupné dáta pre uskutočnenie $\chi^{2}$ - testu nezávislosti boli použité len dáta, ktoré sa týkali zákazníkov spoločnosti Slovak Telecom, a.s. Tento súbor 52 respondentov je podrobnejšie popísaný v tabul'ke 1 .

Tabul'ka 1 Bližšia charakteristika vzorky respondentov

\begin{tabular}{|c|l|l|}
\hline Segmentačné premenné & Absolútna početnost' \\
\hline \multirow{2}{*}{ pohlavie } & muž & 19 respondentov \\
& žena & 33 respondentov \\
\hline \multirow{3}{*}{ vek } & $18-25$ rokov & 20 respondentov \\
& $26-30$ rokov & 7 respondentov \\
& $31-40$ rokov & 8 respondentov \\
& $41-50$ rokov & 11 respondentov \\
& $51-60$ rokov & 6 respondentov \\
\hline \multirow{2}{*}{ vzdelanie } & základné & 3 respondentov \\
& stredoškolské & 34 respondentov \\
& vysokoškolské & 15 respondentov \\
\hline \multirow{2}{*}{ povolanie } & študent & 15 respondentov \\
& zamestnanec & 22 respondentov \\
& podnikatel' & 9 respondentov \\
& nezamestnaný & 6 respondentov \\
\hline
\end{tabular}

\section{Test nezávislosti v kontingenčných tabul'kách}

Majme dvojrozmerný náhodný vektor $X=(Y, Z)^{\prime}$, pričom $Y$ môže nadobúdat' hodnoty $1,2, \ldots, r$ a Z môže nadobúdat' hodnoty $1,2, \ldots, c, r>1, c>1$.

Označíme

$$
\begin{aligned}
& p_{i j}=P(Y=i, Z=j), \\
& p_{i .}=P(Y=i)=\sum_{j=1}^{c} p_{i j}, \\
& p_{. j}=P(Z=j)=\sum_{i=1}^{r} p_{i j} .
\end{aligned}
$$

Pritom predpokladáme, že platí $p_{i j}>0$ pre každé $(i, j)$. Čísla $n_{i .}$ a $n_{. j}$ sa nazývajú marginálne početnosti.

Uvažujme náhodný výber s rozsahom $n$ s rozdelením s pravdepodobnost’ami $p_{i j}$. Ak označíme $n_{i j}$ počet tých prípadov, kde súčasne nastalo $Y=i$ a $Z=j$, tak môžeme výsledky zapísat' do kontingenčnej tabul'ky. 
V kontingenčných tabul'kách sa najčastejšie testuje hypotéza, že veličiny $Y$ a $Z$ sú nezávislé. Za platnosti nulovej hypotézy $\mathrm{H}_{0}: Y$ a $Z$ sú nezávislé má veličina

$$
\chi^{2}=\sum_{i=1}^{r} \sum_{j=1}^{c} \frac{\left(n_{i j}-\frac{n_{i \cdot} \cdot n_{. j}}{n}\right)^{2}}{\frac{n_{i .} \cdot n_{. j}}{n}}
$$

asymptoticky $\chi^{2}$ - rozdelenie s počtom stupňov vol'nosti

$$
f=r c-(r+c-2)-1=(r-1)(c-1) .
$$

Ak dostaneme $\chi^{2} \geq \chi_{(r-1)(c-1)}^{2}(\alpha)$, zamietame hypotézu o nezávislosti na hladine významnosti $\alpha$.

Vzorec pre výpočet testovacej štatistiky $\chi^{2}$ sa dá upravit' na jednoduchší tvar:

$$
\chi^{2}=n \sum_{i=1}^{r} \sum_{j=1}^{c} \frac{n_{i j}^{2}}{n_{i \cdot} \cdot n_{. j}}-n .
$$

Veličina $\chi^{2}$ je len testovacou štatistikou, nie je mierou závislosti medzi $Y$ a $Z$.

\section{Prezentácia výsledkov v rámci jednotlivých kl’účových dimenzií kvality služby}

Existuje viacero nástrojov a metód slúžiacich na meranie kvality služieb. Jedným zo špecifických nástrojov, ktorý sa využíva v širokom spektre služieb či už v komerčných alebo v nekomerčných organizáciách je tzv. SERVQUAL. Kombinuje sa v ňom meranie postoja (subjektívneho správania sa poskytovatel'a služby) s meraním spokojnosti ako vnímatel'nej zhody medzi očakávaniami a poskytovanými službami. V rámci tohto príspevku SERVQUAL slúži len pre poskytnutie základnej štruktúry piatich dimenzií kvality služieb, v rámci ktorých sa hodnotila miera spokojnosti zákazníka a skúmala existencia závislosti medzi vybraným trhovým segmentom a jeho hodnotením kvality služieb.

\section{Spol'ahlivost'}

Spol'ahlivost' predstavuje schopnost' realizovat' resp. poskytnút' sl'úbený výkon spol'ahlivo, presne a správne. Pri tomto faktore je vel'mi dôležitá skutočnost', či sa môžeme na poskytovatel'a služby spol'ahnút'. V prípade, že je nespol'ahlivý, robí chyby alebo nedodrží sl'uby, ktorými chce získat' nových zákazníkov, stratí dôveru a znižuje svoje šance vybudovat' si dobré meno na trhu.

Spol'ahlivost' sa vyžaduje nielen pri službách s vysokým finančným vkladom, ale aj pri takých službách, pri ktorých riskujeme svoje zdravie a hodnoty. Spol'ahlivost' sa tiež zvykne označovat' ako srdce kvality služby.

Tabul'ka 1 Skúmanie existencie závislosti medzi vybraným trhovým segmentom a hodnotením kvality služieb v rámci 1. dimenzie - spol'ahlivost'

\begin{tabular}{|l|l|l|l|l|}
\hline \multicolumn{4}{|l|}{} & \multicolumn{4}{l}{ Vybrané segmentačné premenné } \\
\cline { 2 - 5 } \multicolumn{2}{l|}{ pohlavie } & vek & vzdelanie & povolanie \\
\hline$\chi^{2}-$ test nezávislosti & 15,77 & 7,28 & 17,35 \\
\hline $\begin{array}{l}\text { Hodnota testovacej } \\
\text { štatistiky }\end{array}$ & 2,704 & 31,4 & 18,3 & 25 \\
\hline Kritická hodnota & 11,1 & závislé & závislé & závislé \\
\hline Závislost' & závislé & \multicolumn{2}{|l}{} \\
\hline
\end{tabular}




\section{Vnímavost', prístupnost'}

Vnímavost' a prístupnost' ako jedna z dimenzií kvality služieb zahŕňa dve základné kritéria, a to rýchlost' a ochotu pri riešení zákazníkových problémov. V rámci tejto dimenzie sa hodnotí sa, či zamestnanci reagujú pohotovo a tvorivo na želania a problémy zákazníkov a zároveň či je l'ahká dostupnost' na vhodnom mieste, vo vhodnom čase a s krátkou dobou čakania.

Tabul'ka 2 Skúmanie existencie závislosti medzi vybraným trhovým segmentom a hodnotením kvality služieb v rámci 2. dimenzie - vnímavost' a prístupnost'

\begin{tabular}{|l|l|l|l|l|}
\hline \multicolumn{4}{|l|}{} & \multicolumn{4}{l}{ Vybrané segmentačné premenné } \\
\cline { 2 - 5 } \multicolumn{2}{l|}{ pohlavie } & vek & vzdelanie & povolanie \\
\hline$\chi^{2}-$ test nezávislosti & 37,43 & 17,88 & 28,12 \\
\hline $\begin{array}{l}\text { Hodnota testovacej } \\
\text { štatistiky }\end{array}$ & 4,905 & 46,2 & 26,3 & 36,4 \\
\hline Kritická hodnota & 15,5 & závislé & závislé & závislé \\
\hline Závislost' & závislé & \multicolumn{2}{l}{} \\
\hline
\end{tabular}

\section{Istota a kompetencie}

Medzi základné hodnotiace kritériá patrí zdvorilost', priatel'skost', odbornost' a spôsobilost' zamestnancov pri samotnom poskytovaní služieb. Taktiež sa sem možno zaradit' schopnost' vzbudzovat' dôveru u zákazníkov. Hodnotí sa napríklad, či služba nie je spojená s nebezpečenstvom, rizikom alebo neistotou, ale aj disponovanie požadovanými schopnost’ami, zručnost’ami, znalost’ami v záujme bezchybného poskytnutia služby.

Tabul'ka 3 Skúmanie existencie závislosti medzi vybraným trhovým segmentom a hodnotením kvality služieb v rámci 3. dimenzie - istota a kompetencie

\begin{tabular}{|c|c|c|c|c|}
\hline & \multicolumn{4}{|c|}{ Vybrané segmentačné premenné } \\
\hline & pohlavie & vek & vzdelanie & povolanie \\
\hline \multicolumn{5}{|l|}{$\chi^{2}-$ test nezávislosti } \\
\hline $\begin{array}{l}\text { Hodnota testovacej } \\
\text { štatistiky }\end{array}$ & 4,36 & 14,768 & 8,306 & 14,33 \\
\hline Kritická hodnota & 12,6 & 36,4 & 21 & 28,9 \\
\hline Závislost' & závislé & závislé & závislé & závislé \\
\hline
\end{tabular}

\section{Empatia}

Rozumieme ňou individuálnu pozornost' zo strany poskytovatel'a služby, ktorú venuje svojmu zákazníkovi. Je to schopnost' vcítit' sa do duševného stavu zákazníka, do jeho potrieb. Zamestnanec, ktorý je v styku s klientom, by mal mat' schopnost' načúvat' tomu, čo klient vyžaduje. Najväčší význam má schopnost’ prispôsobit' sa zákazníkovým požiadavkám.

Tabul'ka 4 Skúmanie existencie závislosti medzi vybraným trhovým segmentom a hodnotením kvality služieb v rámci 4. dimenzie - empatia

\begin{tabular}{|l|l|l|l|l|}
\hline \multicolumn{4}{|l|}{} & \multicolumn{4}{l}{} \\
\cline { 2 - 5 } \multicolumn{2}{l|}{ pybrané segmentačné premenné } \\
\hline$\chi^{2}-$ test nezávislosti & vek & vzdelanie & povolanie \\
\hline $\begin{array}{l}\text { Hodnota testovacej } \\
\text { štatistiky }\end{array}$ & 14,097 & 30,39 & 20,81 & 54,04 \\
\hline Kritická hodnota & 18,3 & 55,8 & 31,4 & 43,8 \\
\hline Závislost' & závislé & závislé & závislé & nezávislé \\
\hline
\end{tabular}




\section{Hmotné skutočnosti}

Táto dimenzia kvality služby zahŕňa výhody vyplývajúce z vybavenia budovami, technickými zariadeniami a komunikačnými siet'ami. Hodnotí sa existencia a prítomnost' fyzického vybavenia a zariadenia, a to pre personál všeobecne a kontaktný zvlášt'.

Tabul'ka 5 Skúmanie existencie závislosti medzi vybraným trhovým segmentom a hodnotením kvality služieb v rámci 5. dimenzie - hmotné skutočnosti

\begin{tabular}{|l|l|l|l|l|}
\hline \multicolumn{4}{|l|}{} & \multicolumn{4}{l}{} \\
\cline { 2 - 5 } \multicolumn{2}{l|}{ pybrané segmentačné premenné } \\
\hline$\chi \chi^{2}-$ test nezávislosti & vek & vzdelanie & povolanie \\
\hline $\begin{array}{l}\text { Hodnota testovacej } \\
\text { štatistiky }\end{array}$ & 6,85 & 12,52 & 15,2 & 23,48 \\
\hline Kritická hodnota & 18,3 & 60,1 & 31,4 & 43,8 \\
\hline Závislost' & závislé & závislé & závislé & závislé \\
\hline
\end{tabular}

\section{Záver}

Je samozrejmé, že existuje mnoho možností pre segmentáciu trhu. Treba však zdôraznit', že nie všetky sú efektívne. Skutočnost', že na základe výsledkov testu nezávislosti v kontingenčných tabul'kách sa až na jednu výnimku potvrdila skutočnost', že existujú špecifické postoje zvolených segmentov kjednotlivým dimenziám kvality poskytovanej služby, ešte neznamená, že možno hovorit' o splnení požiadavky na efektívnu segmentáciu. Efektívne trhové segmenty musia totiž splnit' viaceré kritéria. Musia byt':

- meratel'né - musí byt' možné zmerat' vel'kost', kúpnu silu a d'alšie charakteristiky trhového segmentu. Tejto požiadavke zodpovedajú demografické a geografické kritériá.

- výdatné - natol'ko vel'ké, aby sa vyplatilo ich obsluhovat', mali by reprezentovat' čo najväčšiu homogénnu skupinu zákazníkov, pre ktorú je efektívne implementovat' špecifický marketingový program,

- dostupné - efektívne dosiahnutel'né a obsluhovatel'né (napr. reklamnou kampaňou),

- diferencovatel'né - natol'ko odlišné, aby bolo možné pre ne implementovat' efektívne marketingové programy,

- akcieschopné - také, aby bolo možné formovat' marketingové programy, ktoré umožnia pritiahnut' a obsluhovat' ciel'ových zákazníkov.

Ked' firma identifikuje trhové príležitosti jednotlivých segmentov, musí sa rozhodnút' do ktorých z nich vstúpi. Pri hodnotení segmentov treba brat' do úvahy ich prít’ažlivost', ciele firmy a disponibilné zdroje. Firma sa môže sústredit' na jediný segment, na niekol'ko segmentov, na špecifický produkt, na špecifický trh alebo na celý trh. Ak sa chce firma zamerat' na celý trh, je potrebné aby si vybrala medzi diferencovaným a nediferencovaným marketingom. O diferencovanom marketingu hovoríme v prípade, ked' podnik pôsobí na väčšine trhových segmentov, ale pre každý uplatňuje rozdielne marketingové programy.

\section{Literatúra}

[1] KLUČÁROVÁ, M.: Hodnotenie úrovne predajných procesov v sieti telekomunikačných operátorov, diplomová práca č. 28/2005

[2] KOTLER, P.: Marketing management. Praha : Grada Publishing, 2001. 719 s. ISBN 80-247-0016-6.

[3] MICHALOVÁ, V.: Manažment a marketing v trhových službách. Bratislava: Sprint, 1999. 209s. ISBN 80-88848-53-9

[4] ANDĚL, J.: Matematická statistika. Praha: SNTL/Alfa, 1985. 352 s. 